\title{
Brassinosteroids Improve Quality of Table Grapes (Vitis vinifera L.) $c v$. Flame Seedless
}

\author{
W.A. Harindra Champa ${ }^{*}$, M.I.S. Gill ${ }^{1}$, B.V.C. Mahajan ${ }^{2}$, N.K. Aror $^{1}$ and Seema Bedi ${ }^{3}$
}

\author{
Department of Fruit Science \\ Punjab Agricultural University \\ Ludhiana 141004 \\ Punjab, India
}

\begin{abstract}
Significance of preharvest foliar sprays of brassinosteroid (BRs) on physicochemical properties and postharvest life of table grape cv. Flame Seedless were studied. The experiment was performed on 12-year old own rooted, grapevines planted at $3 \mathrm{~m}$ $x 3 \mathrm{~m}$ spacing trained on overhead system. Vines were treated with aqueous solutions of BRs $\left(0.0,0.1,0.5\right.$ and $\left.1.0 \mathrm{mg} \mathrm{l}^{-1}\right)$ at pea stage and at veraison. After harvesting, clusters were divided into two lots in which one was subjected to initial quality evaluation, while the other was stored in cold room $\left(3-4{ }^{\circ} \mathrm{C}, 90-95 \% \mathrm{RH}\right)$ for evaluation of postharvest quality. Clusters treated with 0.5 and $1.0 \mathrm{mg} \mathrm{l}^{-1}$ BRs showed significant increase in cluster weight and breadth as well as berry weight, length and breadth. BRs, at the dose of $0.5 \mathrm{mg} \mathrm{l}^{-1}$ effectively reduced the rate of berry softening, maintained external colour, stabilized anthocyanins, increased total phenols along with reduced rate of degradation in TSS and TA during low temperature storage on the contrary to other two doses and the control. It also exhibited protective role against decay development. Preharvest foliar spray of $0.5 \mathrm{mg} \mathrm{l}^{-1}$ BRs could be an effective means of maintaining quality and extending postharvest life of grape cv. Flame Seedless during cold storage.
\end{abstract}

Keywords: Anthocyanin, phenol, physicochemical properties, postharvest, viticulture

\section{INTRODUCTION}

Brassinosteroids (BRs) are a group of steroidal plant hormones that are essential for normal plant growth and development (Clouse and Sasse, 1998).In higher plants they play a critical role in a range of developmental processes including stem and root growth, floral initiation, and the development of flowers and fruits (Bajguz and Hayat, 2008). BRs have also been implicated in plant responses to a wide range of abiotic stresses such as drought, salinity, thermal and oxidative stresses as well as biotic stress (Bajguz and Hayat, 2008). There is convincing evidence that preharvest treatments of BRs advanced fruit ripening (Symons et al., 2006), increased fruit firmness (Peng et al., 2004) and during postharvest it reduced

\footnotetext{
Department of Fruit Science, Punjab Agricultural University, Ludhiana 141 004, India

Punjab Horticultural Post harvest Technology Centre, Punjab Agricultural University, Ludhiana 141 004, India.

3 Department of Botany, Punjab Agricultural University, Ludhiana, 141 004, India.

* Corresponding author: harindra74@gmail.com
} 
decay causing organisms and delayed fruit senescence by suppression of rates of respiration and ethylene production (Zhu et al., 2010).

Grape (Vitis vinifera L.) cv. Flame Seedless has been recommended by the Punjab Agricultural University quite recently for commercial cultivation in Punjab and adjoining states of North India. Berries of Flame Seedless are light red coloured, ripen during first fortnight of June and has higher total soluble solids (TSS) and lower juice acidity. However, berry size of this variety is medium and the colour development within the cluster is uneven. If the berry size and colour quality could be improved further along with enhanced postharvest life, the crop would fetch premium prices raising its economic value.

Attempts have been made to improve its berry size and colour by adopting cultural practices such as crop load management along with foliar application of ethephon (an ethylene releasing compound - 2-chloroethyl phosphonic acid). However, ethylene is a growth retardant that would pose negative impact on important physical properties of the berries such as size, weight and firmness. Furthermore, since it releases ethylene, can drift and get absorbed by the leaves, causing yellowing and defoliation. This would adversely affect vine productivity in the current season and sprouting in the following season (Roberto et al., 2012).

Therefore, the present study was conducted to investigate the effect of BRs on physicochemical properties of berries and its effect on postharvest life during low temperature storage of grape $c v$. Flame Seedless.

\section{METHODOLOGY}

\section{Plant material and brassinosteroids application}

The experiment was performed on 12-year old own rooted grapevine (Vitis vinifera L.) $c v$. Flame Seedless planted at $3 \mathrm{~m} \times 3 \mathrm{~m}$ spacing (440 plants per acre) trained on bower (overhead) system in the vineyard of "New Orchard", Department of Fruit Science, Punjab Agricultural University, Ludhiana, Punjab, India during 2013 cropping season. Twenty vines ( 5 vines per treatment) having a girth diameter of $7.22 \pm 1.02 \mathrm{~cm}$ which bear $60-80$ canes (4 buds per cane) were chosen and uniform cultural practices were adopted as per the recommendations (Anon, 2010). Aqueous solutions of BRs (0.0 - control, 0.1, 0.5 and 1.0 $\mathrm{mg} \mathrm{l}^{-1}$, Proactive Bioscience, India) were prepared by dissolving them in a small amount of ethanol and bringing to the final volume of 251 with water. A surfactant Tween $20^{\circledR}$ (Polyoxy ethylenesorbitan monolaurate polyethylene glycol, Sigma Aldrich Co., USA) at the rate of $0.1 \%$ was added to obtain better retention and penetration of BRs solution. The prepared solutions were sprayed directly to the clusters of vines (5 1 per vine) at pea stage (4$5 \mathrm{~mm}$ diameter berry size, two weeks after fruit set) and at veraison (approximately $10 \%$ of the berries of $50 \%$ of the clusters become soft and at colour break) by a sprayer machine until runoff in the morning on a sunny day.

\section{Evaluation of physicochemical properties}

At commercial maturity (TSS $\geq 16{ }^{\circ}$ Brix, (Crisosto \& Smilanck, 1994).), bunches were harvested manually, packed in plastic crates of $18-20 \mathrm{~kg}$ capacity and transported to the laboratory of the department immediately. The cluster weight, length and breadth were measured from 10 randomly selected clusters from each vine. The observation on berry 
characters were recorded on the basis of 50 berries taken from 10 bunches. The 50 berries were first weighed to obtain mean berry weight and then placed in a trough so that their ends or equators are gently touched to measure mean berry length and breadth respectively. Specific gravity (SG) was measured by water displacement method. Peel colour of berries was measured by using Hunter lab colour difference meter (ColorFlex ${ }^{\circledR}$ EZ, USA). The values of $L^{*}, a^{*}, b^{*}$ were recorded. Berry firmness was measured using a Texture Analyzer (TA+HDi ${ }^{\circledR}$ Stable Micro Systems, UK) equipped with a HDP/90 platform and $5 \mathrm{~kg}$ load cell. The measurement was made on the equatorial position of the berry with $4 \mathrm{~mm}$ probe at a test speed of $1 \mathrm{~mm} / \mathrm{s}$ to a constant compression distance of $1 \mathrm{~mm}$. The readings were expressed as maximum force in grams (Rolle et al., 2011).

\section{Evaluation of postharvest life}

Well coloured, properly formed bunches that are free from any visible defects were selected for the storage study and $2 \mathrm{~kg}$ of grapes were packed into low density polyethylene film $\left(\mathrm{LDPE}, 37.5 \mu\right.$ ) packages of $3 \mathrm{~kg}$ capacity each containing in-package dual release $\mathrm{SO}_{2}$ generator pad (Grapage ${ }^{\circledR}$ - Sodium Metabisulphite $-40 \%$, JK Enterprises, Pune, India). These primary packages were put in to $2 \mathrm{~kg}$ capacity corrugated fibber board (CFB) boxes and stored in the cold room $\left(3-4^{\circ} \mathrm{C}, 90-95 \% \mathrm{RH}\right)$. The evaluation of physicochemical parameters and other fruit quality attributes were made at harvest (d 0), 30, 45, 60 and 75 days of storage.

\section{Anthocyanins and phenols}

Total anthocyanin content of berries was determined as described by Ranganna (1986) with the extraction solvent ethanolic HCL and absorbance was noted at $535 \mathrm{~nm}$ wavelength by spectrophotometer (Spectronic $200^{+}$, Thermo Scientific). Total phenols were determined by Folin-Ciocalteu method, based on colourimetric oxidation/reduction reaction of phenols (Slinkard and Singleton, 1977). Phenol extraction was carried out with $80 \%$ ethanol and the absorbance was measured at $765 \mathrm{~nm}$ by spectrophotometer (Spectronic 200 ${ }^{+}$, Thermo Scientific) against a blank. The results were expressed as mg of gallic acid equivalents $/ 100 \mathrm{~g}$ FW using a gallic acid standard curve.

\section{Determination of other chemical parameters}

For analysis of other chemical parameters, 50 berries from each replicate were squeezed and the juice obtained was filtered through a cheese cloth. Total soluble solids (TSS) was measured by a temperature compensated digital refracto meter (Atago PAL-1, model 3810, Japan) and expressed as ${ }^{\circ}$ Brix. Titratable acidity (TA) was determined as per AOAC (2005) and expressed as grams of tartaric acid equivalents per $100 \mathrm{ml}$ of juice.

\section{Weight loss, berry shatter, rachis browning and decay incidence}

Weight loss (WL) was recorded by subtracting final weight from the initial weight of the clusters and then expressed as percent weight loss with reference to the initial weight. Percent berry shatter was calculated for each box by dividing the weight of free berries from the total weight of boxed grapes. Rachis condition was rated according to Crisosto et al. (2002), as described. 1 = healthy, entire rachis including the pedicels are green and healthy, 2 $=$ slight, rachis in good condition, but noticeable browning of pedicels, $3=$ moderate, browning of pedicels and secondary rachis, $4=$ severe, pedicels, secondary and primary 
rachis completely brown. Decay incidence was expressed as the proportion (by weight) of rotten berries relative to total weight of berries within each box.

\section{Evaluation of organoleptic quality}

The berries were rated by a panel of 30 untrained judges on the basis of colour, texture, flavour and overall acceptability. A nine point hedonic scale described by Amerine et al. (1965) was used for its inference.

\section{Experimental design and analysis}

In the field, the treatments were distributed according to randomized complete block design with four blocks ( 3 vines per block). In the laboratory, boxes were arranged in complete randomized design (CRD) with three replicates. Data were analyzed for variance by using SAS (V 9.3, SAS Institute Inc., USA) package. When interactions between treatments were significant $(P \leq 0.05)$, the effect of each treatment was determined separating the means by Least Significant Difference (LSD). Data of rachis browning and organoleptic quality was analyzed by Kruskal Wallis test and Friedman test respectively, using MINITAB 15 software (Minitab Inc., USA).

\section{RESULTS AND DISCUSSION}

\section{Cluster and berry physical properties}

A significant increase in cluster weight was observed when vines were sprayed with $1.0 \mathrm{mg}$ $1^{-1}$ BRs compared to control (Table 1). However, there was no significant difference observed in cluster length. Cluster breadth was highest in berries which received $0.5 \mathrm{mg} \mathrm{l}^{-1}$ BRs.

Table 1. Effect of different concentrations of brassinosteroids on cluster weight, length and breadth of Flame Seedless grapes

\begin{tabular}{llll}
\hline $\begin{array}{l}\text { Concentration } \\
\left(\mathbf{m g ~ l} \mathbf{- 1}^{\mathbf{1}}\right)\end{array}$ & Cluster weight $(\mathbf{g})$ & \multicolumn{1}{c}{$\begin{array}{c}\text { Cluster length } \\
(\mathbf{c m})\end{array}$} & $\begin{array}{c}\text { Cluster breadth } \\
(\mathbf{c m})\end{array}$ \\
\hline 0.0 & $220.0^{\mathrm{c}}$ & $23.17^{\mathrm{a}}$ & $13.13^{\mathrm{b}}$ \\
0.1 & $266.7^{\mathrm{b}}$ & $25.67^{\mathrm{a}}$ & $13.00^{\mathrm{b}}$ \\
0.5 & $266.7^{\mathrm{b}}$ & $26.00^{\mathrm{a}}$ & $17.15^{\mathrm{a}}$ \\
1.0 & $285.0^{\mathrm{a}}$ & $25.17^{\mathrm{a}}$ & $13.3^{\mathrm{b}}$ \\
$p$ & 0.01 & $\mathrm{NS}$ & 0.0024 \\
$L S D$ & 12.15 & - & 2.04 \\
\hline
\end{tabular}

Means in a column with the same letter are not significantly different (at $\mathrm{p}=0.05)$ according to $\mathrm{LSD},(\mathrm{n}=10)$, NS: not significant.

Berry weight, length and breadth were prominently higher in clusters treated with 0.5 and 1.0 mg $1^{-1}$ BRs (Table 2) on the contrary to control. None of the BRs treatments could affect berry specific gravity significantly (Table 2). Specific gravity is the guiding index to judge the physiological maturity of the fruits and is established as a reliable index for some fruits such as mango (Pantastico, 1975), but not for grapes.BRs induced cell division, expansion and differentiation are well documented (Sasse, 2003; Taiz \& Zeiger, 2010). Endogenous BRs even at nanomolar concentrations enhance the growth of tissues synergistically and in an independent manner to auxin (Taiz \& Zeiger, 2010). Positive effect of BRs on these 
parameters is an advantage because best price of table grapes are always fetched by clusters with large berries both in domestic and export markets. These results comply with those reported by Warusavitharana et al. (2008) and Bhat et al. (2011) in grapes Peng et al. (2004) in litchi and Gomez et al. (2006) in yellow passion fruit.

Table 2. Effect of different concentrations of brassinosteroids on berry physical properties of flame seedless grapes

\begin{tabular}{|c|c|c|c|c|}
\hline $\begin{array}{l}\text { Concentration } \\
\left(\mathrm{mg} \mathrm{l}^{-1}\right)\end{array}$ & $\begin{array}{l}\text { Berry weight } \\
\text { (g) }\end{array}$ & $\begin{array}{l}\text { Berry length } \\
\text { (cm) }\end{array}$ & $\begin{array}{l}\text { Berry breadth } \\
\text { (cm) }\end{array}$ & $\begin{array}{l}\text { Specific } \\
\text { gravity } \\
\left(\mathrm{g} \mathrm{cm}^{-3}\right)\end{array}$ \\
\hline 0.0 & $2.38^{\mathrm{b}}$ & $1.71^{b}$ & $1.59^{\mathrm{b}}$ & $1.11^{\mathrm{a}}$ \\
\hline 0.1 & $1.88^{\mathrm{c}}$ & $1.63^{\mathrm{b}}$ & $1.52^{\mathrm{b}}$ & $1.05^{\mathrm{a}}$ \\
\hline 0.5 & $2.55^{\mathrm{a}}$ & $1.84^{\mathrm{a}}$ & $1.73^{\mathrm{a}}$ & $1.07^{\mathrm{a}}$ \\
\hline 1.0 & $2.57^{\mathrm{a}}$ & $1.89^{\mathrm{a}}$ & $1.74^{\mathrm{a}}$ & $1.05^{\mathrm{a}}$ \\
\hline$p$ & 0.01 & 0.03 & 0.02 & NS \\
\hline$L S D$ & 0.14 & 0.12 & 0.07 & - \\
\hline
\end{tabular}

Means in a column with the same letter are not significantly different (at $\mathrm{p}=0.05)$ according to LSD, $(\mathrm{n}=50$; for specific gravity $n=10)$, NS: not significant.

\section{Firmness}

Firmness of grape berries with or without BRs treatment decreased during low temperature storage (Figure 1A). However, clusters sprayed with BRs maintained higher berry firmness in comparison to control. Out of 3 doses examined, clusters treated by 0.1 and $0.5 \mathrm{mg} \mathrm{l}^{-1}$ of BRs displayed higher efficacy in maintaining berry firmness on the contrary to the highest dose $\left(1.0 \mathrm{mg} \mathrm{l}^{-1}\right)$. Maintenance of higher firmness with BRs treatment has been reported by Peng et al. (2004) in litchi and Zhu et al. (2010) in jujube. BRs enhance fruit firmness by increasing $\mathrm{Ca}^{2+,}$ protopectin and pectin of cell walls (Peng et al., 2004).

\section{Peel colour and anthocyanins}

Irrespective of the treatments, $L^{*}$ (lightness) and $b^{*}$ value decreased over the 75 days of storage (DOS) period while $a^{*}$ value showed increasing trend up to 45 DOS and then decreased (Table 3). However, rate of variation in colour during cold storage varied among treatments and the control.

The clusters received 0.5 and $1.0 \mathrm{mg} \mathrm{l}^{-1}$ BRs retarded the rate of deviation of $L^{*}, a^{*}$ and $b^{*}$ from their initial values effectively in comparison to the lowest dose $\left(0.1 \mathrm{mg} \mathrm{l}^{-1}\right)$ and the control. As Flame Seedless berries mature their colour changes from a relatively pure green to yellow, and eventually to red. The pigment responsible for this red colouration is anthocyanins and in $c v$. Flame Seedless cyanidin-3-glucoside is the most abundant pigment (Ferdenandez-Lopez et al., 1998). These pigments are mainly confined to the skin and, the external colour and anthocyanic profile are closely linked (Ferdenandez-Lopez et al., 1998). Anthocyanins are chemically unstable and thus, in detached berries these pigments may easily degrade to undesirable colours which would result mainly from enzymatic oxidation as a consequence of loss of compartmentalization of enzymes and substrates during prolonged storage (Jiang \& Chen, 1995). Total anthocyanin content (TAC) was significantly affected by preharvest foliar sprays of BRs (Figure 1B). At harvest (day 0), TAC was increased in dose dependent manner whereas, during subsequent storage the highest TAC 
was maintained by clusters sprayed with $0.5 \mathrm{mg} \mathrm{l}^{-1}$ BRs on the contrary to other two doses and the control.
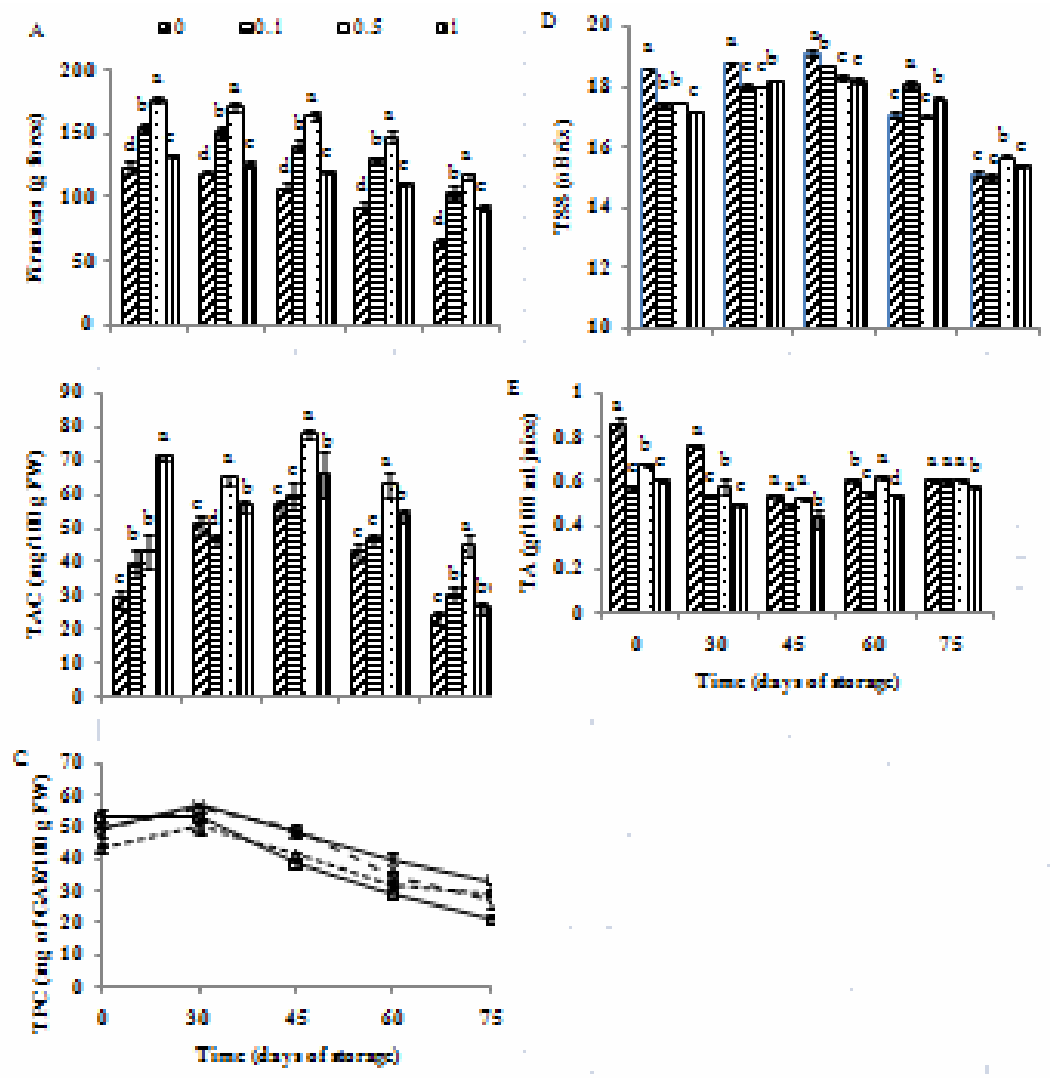

Fig. 1. Variation in firmness (A), total anthocyanin content (TAC, B) total phenol content (TPC, C), total soluble solids (TSS, A) and titratable acidity (TA, B) of grape cv. Flame Seedless during cold storage $\left(3-4^{\circ} \mathrm{C}, 90-95 \% \mathrm{RH}\right)$ in relation to preharvest treatment with different concentrations of brassinosteroids (BRs). 0.0, 0.1, 0.5 and 1.0 represent concentrations of BRs in $\mathrm{mg}^{1^{-1}}$.Vertical bars represent \pm S.E. of means for 3 replicates.

\section{Total phenols}

Total phenol content (TPC) in BRs treated berries first increased, and came to a peak at day 30 , which then showed a declining trend for the rest of the period whereas, control group exhibited quite stable TPC at harvest (0 day) up to 30 DOS (Figure 1C). After this point, the TPC in control group also decreased gradually BRs increased TPC of berries in dose dependent manner and all three concentrations maintained significantly higher TPC on the contrary to control. Zhu et al. (2010) and Aghdam et al. (2012) observed that exogenous BRs treatment enhance phenylalanine ammonia-lyase (PAL) activity, an enzyme that starts the onset of synthesis of free phenolics. Our results comply with Aghdam et al. (2012) who observed subsequent increase in total phenols with BRs treatment in tomato fruit. 
Table 3. Effect of various concentrations of brassinosteroids on external colour $\left(L^{*}, a^{*}\right.$ and $\left.b^{*}\right)$ of Flame Seedless grape berries during low temperature storage

\begin{tabular}{|c|c|c|c|c|c|}
\hline \multirow{2}{*}{$\begin{array}{l}\text { Parameter and } \\
\text { brassinosteroidsConce } \\
\text { ntration }\left(\mathrm{mg} \mathrm{l}^{-1}\right)\end{array}$} & \multicolumn{5}{|c|}{ Time (days of storage) } \\
\hline & $\mathbf{0}$ & 30 & 45 & 60 & 75 \\
\hline \multicolumn{6}{|l|}{$L^{*}$} \\
\hline 0.0 & $24.8 \pm 0.6^{\mathrm{a}}$ & $19.1 \pm 0.1^{\mathrm{a}}$ & $16.2 \pm 0.3^{\mathrm{b}}$ & $16.2 \pm 0.4^{b}$ & $15.4 \pm 0.2^{\mathrm{b}}$ \\
\hline 0.1 & $25.1 \pm 0.8^{\mathrm{a}}$ & $19.0 \pm 0.9^{\mathrm{a}}$ & $15.4 \pm 0.0^{\mathrm{c}}$ & $15.0 \pm 0.0^{\mathrm{c}}$ & $15.4 \pm 0.1^{b}$ \\
\hline 0.5 & $23.3 \pm 0.2^{\mathrm{b}}$ & $19.7 \pm 0.2^{\mathrm{a}}$ & $18.5 \pm 0.4^{\mathrm{a}}$ & $17.7 \pm 0.5^{\mathrm{a}}$ & $16.1 \pm 0.2^{\mathrm{a}}$ \\
\hline 1.0 & $21.4 \pm 1.0^{\mathrm{c}}$ & $18.9 \pm 0.6^{b}$ & $18.3 \pm 0.4^{\mathrm{a}}$ & $16.6 \pm 0.2^{\mathrm{b}}$ & $15.1 \pm 0.3^{\mathrm{b}}$ \\
\hline $\operatorname{LSD}(\mathrm{P}<0.05)$ & 1.38 & 1.02 & 0.56 & 0.65 & 0.46 \\
\hline \multicolumn{6}{|l|}{$a^{*}$} \\
\hline 0.0 & $2.4 \pm 0.0^{\mathrm{a}}$ & $4.3 \pm 0.0^{\mathrm{b}}$ & $4.5 \pm 0.1^{\mathrm{d}}$ & $3.3 \pm 0.1^{\mathrm{b}}$ & $3.1 \pm 0.1^{\mathrm{b}}$ \\
\hline 0.1 & $1.4 \pm 0.2^{\mathrm{b}}$ & $3.9 \pm 0.3^{\mathrm{b}}$ & $5.5 \pm 0.0^{c}$ & $4.3 \pm 0.4^{\mathrm{a}}$ & $3.5 \pm 0.1^{\mathrm{a}}$ \\
\hline 0.5 & $1.4 \pm 0.2^{\mathrm{b}}$ & $4.2 \pm 0.3^{\mathrm{b}}$ & $5.7 \pm 0.1^{b}$ & $4.2 \pm 0.4^{\mathrm{a}}$ & $2.9 \pm 0.2^{b}$ \\
\hline 1.0 & $2.9 \pm 0.5^{\mathrm{a}}$ & $5.9 \pm 0.3^{\mathrm{a}}$ & $6.5 \pm 0.1^{\mathrm{a}}$ & $3.9 \pm 0.2^{\mathrm{ab}}$ & $3.1 \pm 0.2^{\mathrm{b}}$ \\
\hline $\operatorname{LSD}(\mathrm{P}<0.05)$ & 0.535 & 0.492 & 0.154 & 0.614 & 0.281 \\
\hline \multicolumn{6}{|l|}{$b^{*}$} \\
\hline 0.0 & $3.1 \pm 0.3^{\mathrm{b}}$ & $2.6 \pm 0.1^{\mathrm{a}}$ & $1.9 \pm 0.0^{\mathrm{b}}$ & $1.1 \pm 0.1^{\mathrm{b}}$ & $0.1 \pm 0.0^{\mathrm{c}}$ \\
\hline 0.1 & $3.6 \pm 0.0^{\mathrm{a}}$ & $1.6 \pm 0.0^{\mathrm{c}}$ & $1.5 \pm 0.1^{\mathrm{c}}$ & $0.9 \pm 0.0^{\mathrm{b}}$ & $0.4 \pm 0.0^{\mathrm{b}}$ \\
\hline 0.5 & $2.7 \pm 0.1^{\mathrm{bc}}$ & $2.3 \pm 0.1^{\mathrm{b}}$ & $2.1 \pm 0.1^{\mathrm{b}}$ & $0.4 \pm 0.1^{\mathrm{c}}$ & $0.9 \pm 0.0^{\mathrm{a}}$ \\
\hline 1.0 & $2.9 \pm 0.1^{\mathrm{c}}$ & $2.5 \pm 0.1^{\mathrm{ab}}$ & $3.8 \pm 0.4^{\mathrm{a}}$ & $1.7 \pm 0.3^{\mathrm{a}}$ & $0.4 \pm 0.1^{b}$ \\
\hline $\operatorname{LSD}(\mathrm{P}<0.05)$ & 0.327 & 0.223 & 0.373 & 0.382 & 0.123 \\
\hline
\end{tabular}

Means in a column with the same letter are not significantly different (at $P<0.05$ ) according to LSD. L* $=0$ : black, 100: white; $a^{*}=(-)$ : greenness, $(+)$ : redness; $b^{*}=(-)$ blueness, $(+)$ : yellowness $(n=30)$.

\section{TSS and TA}

Preharvest BRs treatment showed higher efficacy in reducing the rate of reduction in TSS during cold storage in contrast to control, which showed dramatic reduction of TSS after 45 DOS (Figure 1D). TSS content of control berries was higher than that to the treat berries up to 45 DOS. However, by the end of the experiment, TSS content of control berries reduced by $3.5^{\circ} \mathrm{Brix}$ while this reduction in berries received $0.1,0.5$ and $1.0 \mathrm{mg} \mathrm{l}^{-1}$ BRs were 2.5, 1.8 and $1.8^{\circ}$ Brix respectively. TA was lower in BRs treated berries than that of the control up to 30 DOS (Figure 1E) and by the end of 75 days of low temperature storage period no significant difference was exhibited with the control except the higher dose (1.0 $\mathrm{mg} \mathrm{l}^{-1}$ ). Maintenance of higher TSS and TA over the control with exogenous BRs treatment is in line with Zhu et al. (2010). 


\section{Weight loss and berry shatter}

Weight loss increased progressively with extended storage period even though the rate of increase was dramatic in control group compared to BRs received groups (Figure 2A). Grape clusters sprayed with $0.5 \mathrm{mg}^{-1}$ BRs showed a significantly lower weight loss compared to other two doses $\left(0.1\right.$ and $\left.1.0 \mathrm{mg} \mathrm{l}^{-1}\right)$ and the control. By the end of 75 days of cold storage period cumulative weight loss in control treatment was $6.44 \%$ while this percentage in 0.10 .5 and $1.0 \mathrm{mg} \mathrm{l}^{-1}$ BRs treated clusters were $2.93,1.72$ and $3.89 \%$ respectively.
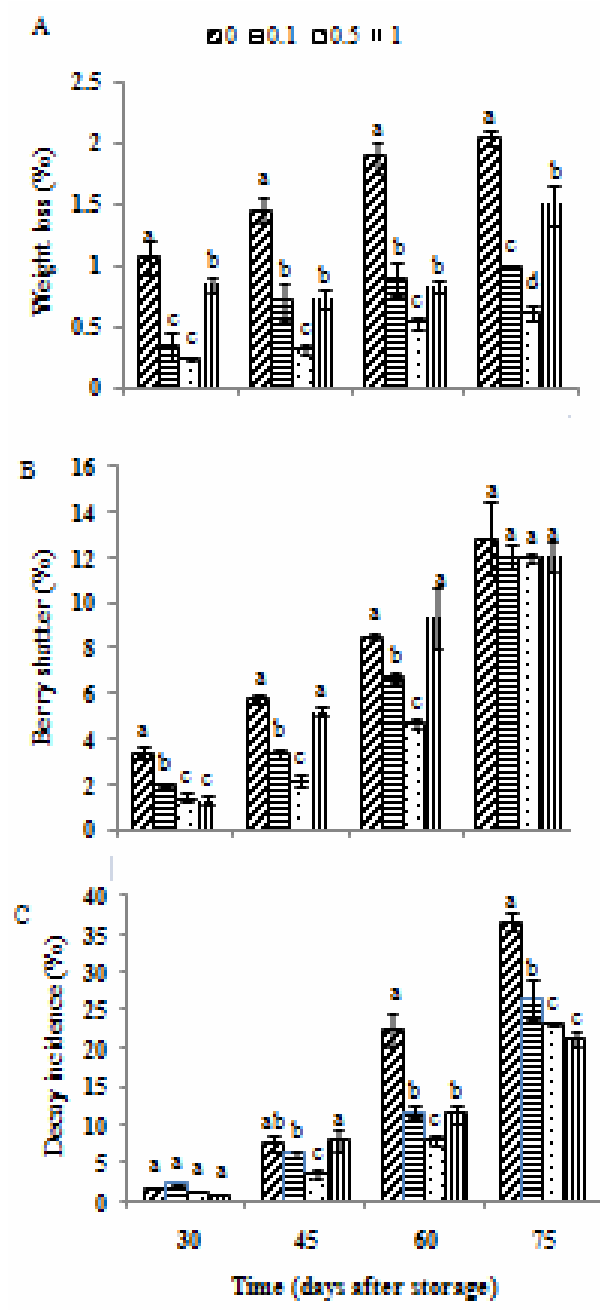

Fig. 2. Variation in weight loss (A), berry shatter $(B)$ and decay incidence $(C)$ of grape cv. Flame Seedless during cold storage $\left(3-4^{\circ} \mathrm{C}, 90-95 \% \mathrm{RH}\right)$ in relation to preharvest treatment with different concentrations of brassinosteroids $0.0,0.1,0.5$ and 1.0 represent concentrations of BRs in $\mathrm{mg} \mathrm{L}^{-1}$. Vertical bars represent \pm S.E. of means for 3 replicates. 
Berry shatter(Figure 2B)demonstrated similar pattern of variation as weight loss and clusters treated by $0.5 \mathrm{mg} \mathrm{l}^{-1}$ BRs effectively reduced the percent berry shatter on the contrary to control and other two doses over the 75 days of cold storage. At the end of experiment, the percent cumulative berry shatter of control, $0.1,0.5$ and $1.0 \mathrm{mg} \mathrm{l}^{-1}$ BRs treated samples were $30.53,24.16,20.30$ and 27.95, respectively. BRs act synergistically as well as in an independent manner to auxin (Taiz and Zeiger, 2010), thus exogenous treatment of BRs effectively suppress rate of ethylene production and respiration (Zhu et al., 2010) leading to lower rate of berry shatter and PLW. Furthermore, it can be assumed that, BRs being antagonistic to ethylene, inhibit weakening of cell walls at the abscission zone by repressing cell wall degrading enzymes such as celllulase and polygalactouronase which might account for lower berry shatter.

\section{Decay incidence}

Decay incidence was significantly affected $(\mathrm{P}<0.05)$ by BRs treatment, however, no significant difference was showed among treated and control groups up to 30 DOS (Figure 2C). Thereafter, BRs at the dose of $0.5 \mathrm{mg}^{-1}$ suppressed decay development significantly up to $60 \mathrm{DOS}$ on the contrary to other two doses $\left(0.1\right.$ and $\left.1.0 \mathrm{mg} \mathrm{l}^{-1}\right)$ and control sample. At the end of experiment, the percent cumulative decay incidence was over $60 \%$ in control grapes, while this percentage was $<50 \%$ in BRs treated grapes. BR has been considered to be involved in a network of interacting signal transduction pathways which regulate defence responses to pathogen stress. Zhu et al. (2010) reported that BRs significantly induced the activities of PAL, polyphenol oxidase (PPO), catalase (CAT) and superoxide dismutase (SOD) in jujube fruit which are involved in the defence response against fungal pathogens. Further, it is suggested that the effects of BRs on reducing decay may be associated with induction of disease resistance in fruit and delay of senescence rather than direct fungi toxicity.

\section{Rachis browning and organoleptic rating}

Rachis quality of grape bunches has been gaining more interest among producers and exporters because of its high impact on the cluster freshness that determines consumer perception (Balic et al., 2012). Preharvest foliar spray of BRs showed higher efficacy in maintaining healthy green rachis during subsequent storage of grapes under low temperature (Table 4). Up to $30 \mathrm{DOS}$, there was no significant difference among treated and control samples with reference to condition of the rachis. However, beyond this point rachis quality was reduced drastically in control clusters showing noticeable browning of pedicels and secondary rachis on 45 DOS while, clusters treated with 0.5 and $1.0 \mathrm{mg} \mathrm{l}^{-1}$ BRs maintained rachis in healthy green condition up to 45 DOS. At veraison, treatment with plant growth regulators, such as abscisic acid (ABA) (Cantin et al., 2007) and cytokinin (Carvajal-Millan et al., 2001; Balic et al., 2012) improved the rachis quality during storage. Findings of the our study showed that, BRs has a better potential in achieving beneficial effects against rachis browning of detached grape clusters. This improvement might account by the direct effect of BRs on suppression of ethylene production (Zhu et al., 2010), which is the main hormone triggering chlorophyll loss and colour fading (Taiz \& Zeiger, 2010) and also the positive effect of BRs on reducing water loss.

Up to 30 DOS, there was no significant difference in organoleptic parameters among treated and control berries (Table 4). However, BRs treatments significantly suppressed decline in sensory qualities up to 60 DOS in cold room $\left(3-4^{\circ} \mathrm{C}, 90-95 \% \mathrm{RH}\right)$ whereas, control samples exhibited poor sensory properties by this stage. Clusters which received 0.5 and $1.0 \mathrm{mg} \mathrm{l}^{-1}$ 
BRs had higher overall acceptability in terms of taste, texture and colour. As has been previously described, positive effects of BRs on physiological and biochemical parameters might account for having better organoleptic properties on the contrary to control.

Table 4. Rachis browning and organoleptic rating of Flame Seedless berries subjected to various treatments of brassinosteroids during low temperature storage

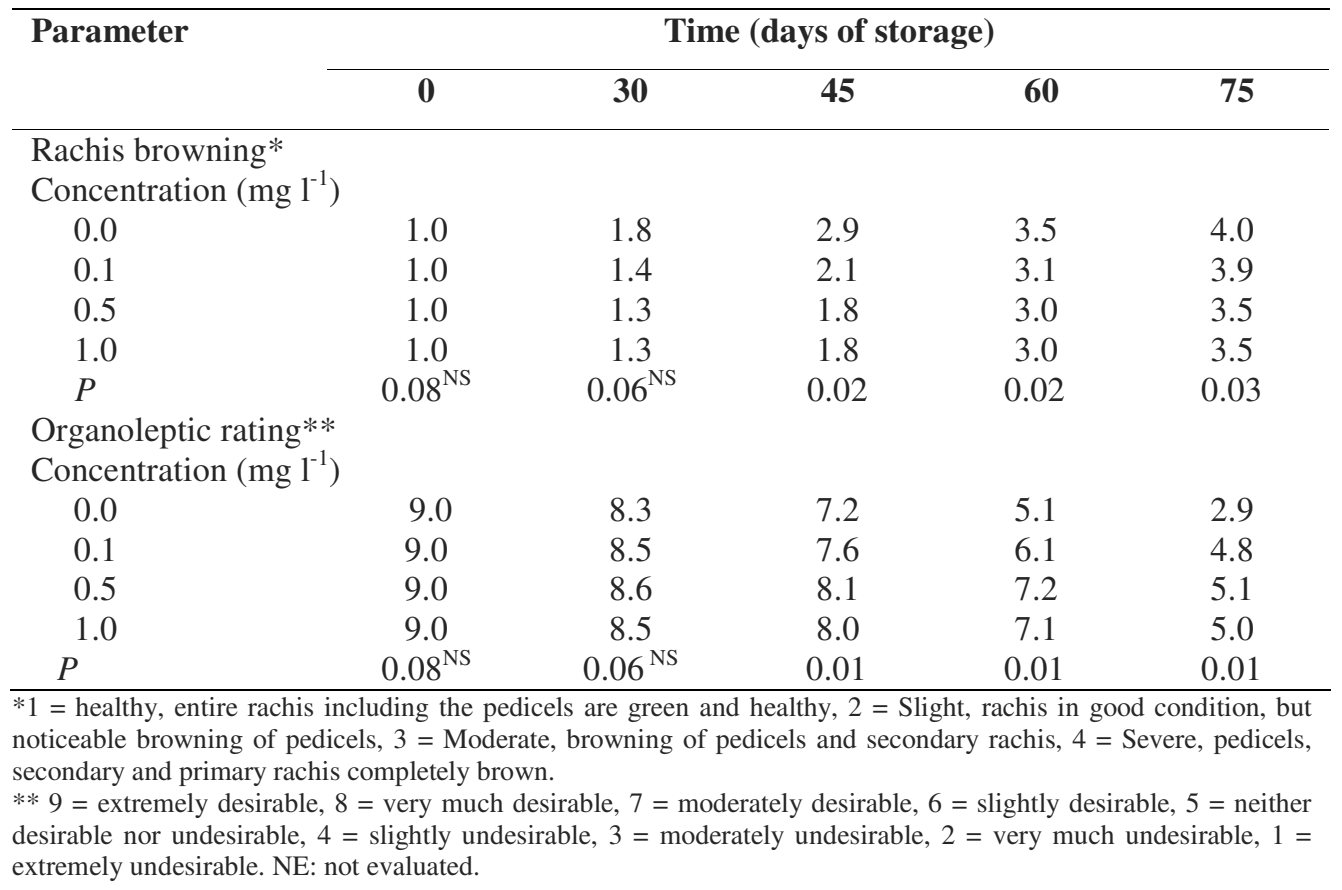

\section{CONCLUSIONS}

Preharvest foliar spray of $0.5 \mathrm{mg}^{-1}$ BRs, at pea stage (4-5 mm diameter berry size, two weeks after fruit set) and at veraision (approximately $10 \%$ of the berries of $50 \%$ of the clusters become soft and at colour break) proved to be effective in maintaining physiological, biochemical and organoleptic qualities of grape $c v$. Flame Seedless under low temperature storage $\left(3-4{ }^{\circ} \mathrm{C}, 90-95 \% \mathrm{RH}\right)$ for up to 60 days in contrast to control which was commercially acceptable only up to 45 days.

\section{REFERENCES}

Aghdam, M.S., Asghari, M., Farmani, B., Mohayeji, M. and Moradbeygi, H. (2012). Impact of postharvest brassinosteroids treatment on PAL activity in tomato fruit in response to chilling stress. Sci. Hort., 144, $116-120$.

Amerine, M.A., Pangborn, R.M. and Roessler, E.B. (1965). Principles of sensory evaluation of food. In: Food Science and Technology Monographs. Academic Press, New York. pp. 338 $-339$. 
Anonymous, (2010). Package of practices for cultivation of fruits. Punjab Agricultural University, Ludhiana, Punjab, India: 63-74.

AOAC (2005). Official Method of Analysis of AOAC International (Vol. II). Suite 500481 , North Frederick Avenue, Gaithersburg, Maryland 20877-2417. USA.

Bajguz, A. and Hayat, S. (2009). Effects of brassinosteroids on the plant responses to environmental stresses: Review. Plant Physiol. Bioche., 47, 1 - 8.

Balic, I., Moreno, A., Sanhueza, D., Huerta, C., Orellana, A., Defillippi, B.G. and CamposVagas, R. (2012). Molecular and physiological study of postharvest rachis browning of table grape cv. Red Globe. Postharvest Biol. Tec., 72, 47 - 56.

Bhat, Z.A., Reddy, Y.N., Srihari, D., Bhat, J.A., Rizwan, R. and Rather, J.A. (2011). New generation growth regulators-brassinosteroids and CPPU improve bunch and berry characteristics in 'Tas-A-Ganesh' grape. Int. J. Fruit Sci., 11, 309 - 315.

Cantin, C.M., Fidelibus, M.W. and Crisosto, C.H. (2007). Application of abscisic acid at veraison advanced red colour development and maintained postharvest quality of Crimson Seedless grapes. Postharvest Biol. Tec., 44, 237 - 241.

Carvajal-Millan, E., Carvallo, T., Orozco, J.A., Martinez, M.A., Tapia, I., Guerrero, V.M., Rascon-Chu, A. Llamas, J. and Gardea, A.A. (2001). Polyphenol oxidise activity, colour changes, and dehydration in table grape rachis during development and storage as affected by N-(2-chloro-4-pyridyl)-N-phenyl urea. J. Agric. Food Chem., 49, 946 - 951.

Clouse, S.D. and Sasse, J.M. (1998). Brassinosteroids: essential regulators of plant growth and development. Annual Rev Plant Physiol. Plant Mol. Biol., 49, 427 - 451.

Crisosto C.H. and Smilanick J.L. (1994). Table grapes postharvest quality maintenance guidelines. Pomology Department, University of California, Davis. CA 95616.

Crisosto, C.H., Garner, D. and Crisosto, G. (2002). Carbon dioxide-enriched atmospheres during cold storage limit losses from Botrytis but accelerate rachis browning of Red Globe table grapes. Postharvest Biol. Tec., 26, 181 - 189.

Fernandez-Lopez, J., Almela, L., Munoz, J.A., Hidalgob, V. and Carreno, J. (1998). Dependence between colour and individual anthocyanin content in ripening grapes. Food Res. Int., 31, 667 - 672.

Gomes, M.M.A., Campostrini, E., Leal, N.R., Viana, A.P., Ferraz, T.M., Siqueira, N.D. and Rosa, R.C.C. (2006). Brassinosteroid analogue effects on the yield of yellow passion fruit plants (Passiflora edulis f. flavicarpa). Sci. Hort., 110, 235 - 240.

Jiang, Y.M. and Chen, F. (1995). A study on polyamine change and browning of fruit during cold storage of litchi (Litchi chinensis Sonn.). Postharvest Biol. Tec, 5, 245 - 250.

Pantastico, E.R.B. (1975). Physicochemical changes during growth of storage organs. Postharvest physiology, handling and utilization of tropical and subtropical fruit and vegetables. pp 41-54. The AVI Publishing Co Inc.Westport, Connecticut. 
Peng J, Tang X and Feng H. (2004). Effects of brassinolide treatment on the physiological properties of litchi pericarp (Litchi chinensis) cv. Nuomoci. Sci. Hort., 101, 407 - 416.

Ranganna, S. (1986). Anthocyanin. Handbook of analysis and quality control of fruit and vegetable products.pp. 94-99.Tata McGrow Hill Publishing Co.Ltd, 7 West Patel Nagar, New Delhi 110008.

Roberto, S.R., Marinho de Assis, A., Yamamoto, L.Y., Miotto, L.C.V., Sato A. J., Renata, K. and Werner, G. (2012). Application timing and concentration of abscisic acid improve colour of 'Benitaka' table grape. Sci. Hort., 142, 44 - 48.

Rolle, L., Simone, G., Vincenzo, G. and Vittorino, N. (2011). Comparative study of texture properties characteristics and chemical of 10 white table-grape varieties. Am. J. Enol. Vitic., 62, 49 - 56.

Sasse, J.M. (2003). Physiological actions of brassinosteroids - an update. J. Plant Growth Regul. 22, 276 - 288.

Slinkard, K. and Singleton, V.L. (1977). Total phenol analysis: automation and comparison with manual methods. Am. J. Enol. Vitic., 28, 49 - 53.

Symons, G.M., Davies, C., Shavrukov, Y., Dry, I.B., Mark, R.T. and Reid, J.B. (2006). Grapes on steroids: brassinosteroids are involved in grape berry ripening. Plant Physiol., 140, $150-158$.

Taiz, L. and Zeiger, E. (2010). Ethylene. Plant physiology, (International ed.), pp. 520-538. Sinauer Associates Inc., Publishers, Sunderland, Massachusetts USA.

Warusavitharana, A.J., Thambe, T.B. and Kshirsagar, D.B. (2008). Effect of cytokinins and brassinosteroid with gibberellic acid on yield and quality of Thompson Seedless grapes. Acta Hort., 785, 217 - 223.

Zhu, Z., Zhanquan, Z., Guozheng, Q. and Shiping, T. (2010). Effects of brassinosteroids on postharvest disease and senescence of jujube fruit in storage. Postharvest Biol. Tec., 56, 50 55. 